\title{
Homogeneity in cranial biometrics and bill morphology is verified by measurements from The Gambia, Botswana and Kenya in the case of the putative sub-species of the highly commensal Hooded Vulture Necrosyrtes monachus monachus and non- commensal Necrosyrtes monachus pileatus
}

\author{
Clive R. Barlow ${ }^{1, *}$, Richard P. Reading ${ }^{2}$, Sidney Shema ${ }^{3}$, \& Glyn Maude ${ }^{2}$ \\ ${ }^{1}$ Birds of The Gambia, Brusubi Gardens, Western Region, The Gambia. \\ ${ }^{2}$ Raptors Botswana, Box Hak 33, Maun, Botswana \\ ${ }^{3}$ Ornithology Section, National Museums of Kenya, P.O. Box 40658 - 00100, Nairobi, Kenya \\ *Corresponding author: birdsofthegambia@ hotmail.com
}

http://dx.doi.org/10.4314/vulnew.v78i1.1

\begin{abstract}
We present biometrical data assembled from a combined total of 37 complete and partially cleaned skulls and feathered heads for the two putative subspecies of Hooded Vulture Necrosyrtes monachus monachus and N. m. pileatus (which Mundy et al. (1992) credibly argue should be N. m. carunculatus). We report on mostly insignificant variation in measurements taken from across three regions of the Hooded Vulture range. For $N . m$. pileatus $(\mathrm{n}=22)$ the measurements are assembled from 13 live birds captured, tagged and released in Botswana between 2014-2017, seven museum specimens held in The National Museums of Kenya collected during 1913-1950, and two as described below. We compare with N. m. monachus (n $=14$ ) where we measured eight specimens produced by road traffic accidents in The Gambia 2002-2019 of which seven are cleaned bare skulls and one a feathered study skin. We also measured six feathered heads and three skulls from several different countries in Africa, collected during 1832-1929 (n = 6 monachus, 2 pileatus, and 1 unknown) and held at the Natural History Museum, Tring, UK. Cranial materials for Hooded Vulture are scarce in world museums and the Gambian sample consisting of seven cleaned skulls represents the largest known number for a single country. Different populations across the regions vary considerably in both feeding habits and home ranges. We hypothesised that different foraging ecologies may have led to adaptation in bill morphology. Presented here for the first time are a series of skull morphometrics which test for variation in cranial biometrics and bill morphology from across the range of the Hooded Vulture. The Gambian bird has been DNA sequenced and a planned genetics study of other populations will resolve the long-standing taxonomic debate.
\end{abstract}

\section{Introduction}

Justification for two subspecies of Hooded Vulture Necrosyrtes monachus monachus and Necrosyrtes monachus pileatus (which Mundy et al. (1992) argue convincingly should be $N$. m. carunculatus) seems weak and confused in the literature (Table 1). Ninety years ago, Bannerman (1930: 183) stated, "A supposed subspecies N. m. pileatus apparently larger in size and with a generally shorter and stouter bill, occurs in South and East Africa, ranging to central Darfur. Those with a wing measurement exceeding $500 \mathrm{~mm}$ are usually assigned to $N$. m. pileatus but I doubt whether pileatus should be recognised at all." Mundy et al. (1992) and del Hoyo (1994) agree that 
the species is perhaps better treated as monotypic, but two subspecies are tentatively recognised. The two putative subspecies involve N. m. monachus (Temminck 1823) in sub-Saharan Africa from $\mathrm{S}$ Mauritania and Senegal E through Niger and Chad to W Sudan, South Sudan and N Uganda and N. $m$. pileatus (Burchell 1824) from E Sudan, Eritrea, Ethiopia and W Somalia S (away from densely forested areas and continuous desert) to N Namibia and Botswana, Zimbabwe, Mozambique and NE
South Africa. More recently, Clark \& Davies (2018: 156) state that, "Two subspecies have been described, but they differ clinally by size not in plumage. Most authorities now consider this species monotypic." Comparative biometric data are lacking and skeletal material for the taxon is scarce in world museums. A genetic study to fully resolve the status of the putative subspecies is planned (Sandi Willows-Munroe personal communication).

Table 1: Compilation of publications and comments dealing with the Hooded Vulture Necrosyrtes monachus sub species issue, 1936-2020.

\begin{tabular}{|c|c|c|}
\hline Author & Year: page & Authors Comments \\
\hline Bannerman & 1936: 183 & $\begin{array}{l}\text { The Common or Hooded Vulture Necrosyrtes monachus monachus. Cathartes } \\
\text { monachus Temminck, Pl. Col. Livr. 38, 1823, pl. 222: Senegal. Neophron } \\
\text { monachus, Sharpe, Cat. Birds Brit. Mus. I. 1874, p. 19; Reich. Vog. Afr. I. } \\
\text { 1901, p. 522. Necrosyrtes monachus monachus, Sclater, Syst. Av. Aethiop. i. } \\
\text { 1924, p. 49. Fig.: Temm. Pl. Col. Pl. 222. } \\
\text { A supposed subspecies N. m. pileatus apparently larger in size with a generally } \\
\text { shorter and stouter bill, occurs in South and East Africa ranging to Central } \\
\text { Darfur. Those with a wing measurement exceeding } 500 \text { mm. are usually } \\
\text { assigned to N. m. pileatus, but I doubt if pileatus should be recognised at all. }\end{array}$ \\
\hline
\end{tabular}

Mackworth-Praed \& $\quad$ 1962: 130

Grant

Mackworth-Praed \& 1970: 106 Grant

Benson et al.

1972: 60

Brown et al

1982: 324
Necrosyrtes monachus pileatus (Burch). Vultur pileatus Burchell, Travels, 2, p. 195, 1824: Hopetown District of Cape Province, South Africa. Distribution of other races: West Africa, the nominate race being described from Senegal.

Necrosyrtes monachus monachus, (Temm.) Cathartes monachus Temminck, Pl. Col. Livr. 38, 1823, pl. 222: Senegal. N. m. pileatus (Burchell) Differs from the nominate monachus race in being larger and having a shorter and less attenuated bill. Wing 481 to $530 \mathrm{~mm}$.

Subspecies N. m, pileatus (Burchell, 1824)
Mundy et al.
1992: 136-138
BoA do not enter a debate and present biometrics of wing, tail \& tarsus for both the nominate monachus and pileatus and for both sexes of each (no bill measurements) e.g., for N. m. monachus (Temminck) wing male av. (470mm) fem av, (484mm) N. m. pileatus (Burchell) generally larger wing male av. (513mm) fem. av. (521mm)

VoA discuss the early descriptions of Hooded Vultures and the purported subspecies, including William John Burchell's description of Vultur pileatus, which was, "most decidedly not a Hooded Vulture." They argue convincingly that the southern form of Hooded Vulture should be Andrew Smith's (1829) 
description of Neophron carunculatus. However, they go on to say that only a clinal variation size distinguishes different populations of Hooded Vultures, variation that does not merit any subspecific designations with the monotypic species.

Del Hoyo

1994

Zimmerman et al.

1996: 340

Borrow \& Demey

Dowsett et al.

Redman et al

Gibbon

Clark \& Davies

Thompson et al.

Gill et al.
2018

2001: 371

2008: 119

2009: 84

2018: 156

2020
Monotypic but mention that two subspecies are sometimes recognised. N. m. monachus (Temminck, 1823) sub-Saharan Africa from S. Mauritania and Senegal E through Niger and Chad to W Sudan, South Sudan and N. Uganda. N. m. pileatus (Burchelll, 1824) E. Sudan, Eritrea, Ethiopia, and W Somalia S (away from densely forested areas and continuous desert) to N Namibia and Botswana, Zimbabwe, Mozambique and NE South Africa. The Checklist (2014) uses the taxonomy of the authors of HBW \& accepts the two subspecies but only tentatively.

Necrosyrtes monachus pileatus

\section{Necrosyrtes monachus monachus}

Taxonomy N. m. pileatus

Race in NE Africa is poorly differentiated pileatus.

Some authorities (eg Brown et al.) recognise 2 subspecies, nominate occurring in W Africa, and N. m. carunculatus (previously N. m. pileatus) in $\mathrm{E}$ and $\mathrm{S}$ Africa. No plumage differences between them, but size increases clinally with southern birds being c. $8 \%$ larger. We ... [treat] the species as monotypic.

Monotypic. Two subspecies have been described, but they differ clinally by size not in plumage. Most authorities now consider this species monotypic.

There are two recognized subspecies of Hooded Vultures, N. m. monachus and $N$. m. pileatus which differ in their degree of commensalism.
Despite their wide distribution, Hooded Vultures have suffered severe population declines across the entire African range and are currently listed as Critically Endangered by the IUCN (Ogada \& Buij 2011). The species remains numerous in some parts of its range; e.g., The Gambia and Guinea-Bissau (Henriques et al. 2018, Jallow et al. 2016, Barlow $\&$ Fulford 2013). The most up to date distribution map for Hooded Vulture created in June 2019 produced by the African Raptor Data Base (personal communication) is presented in Figure 1. The highly commensal West African birds differ considerably in feeding behaviour and in general ecology from their east \& southern African counterparts (Thompson et al 2020, Jallow et al. 2016, Mundy et al. 1992), although more research is needed in this area. There are vast differences in their home ranges as proven by satellite tagging studies (Reading et al. 2019; Thompson et al. 2020). As there is no plumage variation between the 
putative subspecies, we hypothesized that differences in the feeding ecology in the commensal and non-commensal populations may have led to adaptation in bill morphology. Indeed, Bannerman (1936: 183) wrote that pileatus has a generally shorter and stouter bill, whilst Mackworth-Praed \& Grant (1970: 106) followed on that $N$. m. pileatus has ". . . a shorter and less attenuated bill." Thompson et al (2020) base findings of vast home range variation in populations on the two recognized subspecies of
Hooded Vultures, N. m. monachus and N. m. pileatus on differences in their degree of commensalism. We test if any difference in bill morphology is evident in a set of morphometrics measured from live and museum specimens from across West, East, and Southern Africa. We conduct our methodologies following the predominant approach as made known by authors in Table 1 using the sub species monachus and pileatus whilst giving deference to Mundy et al. (1992).

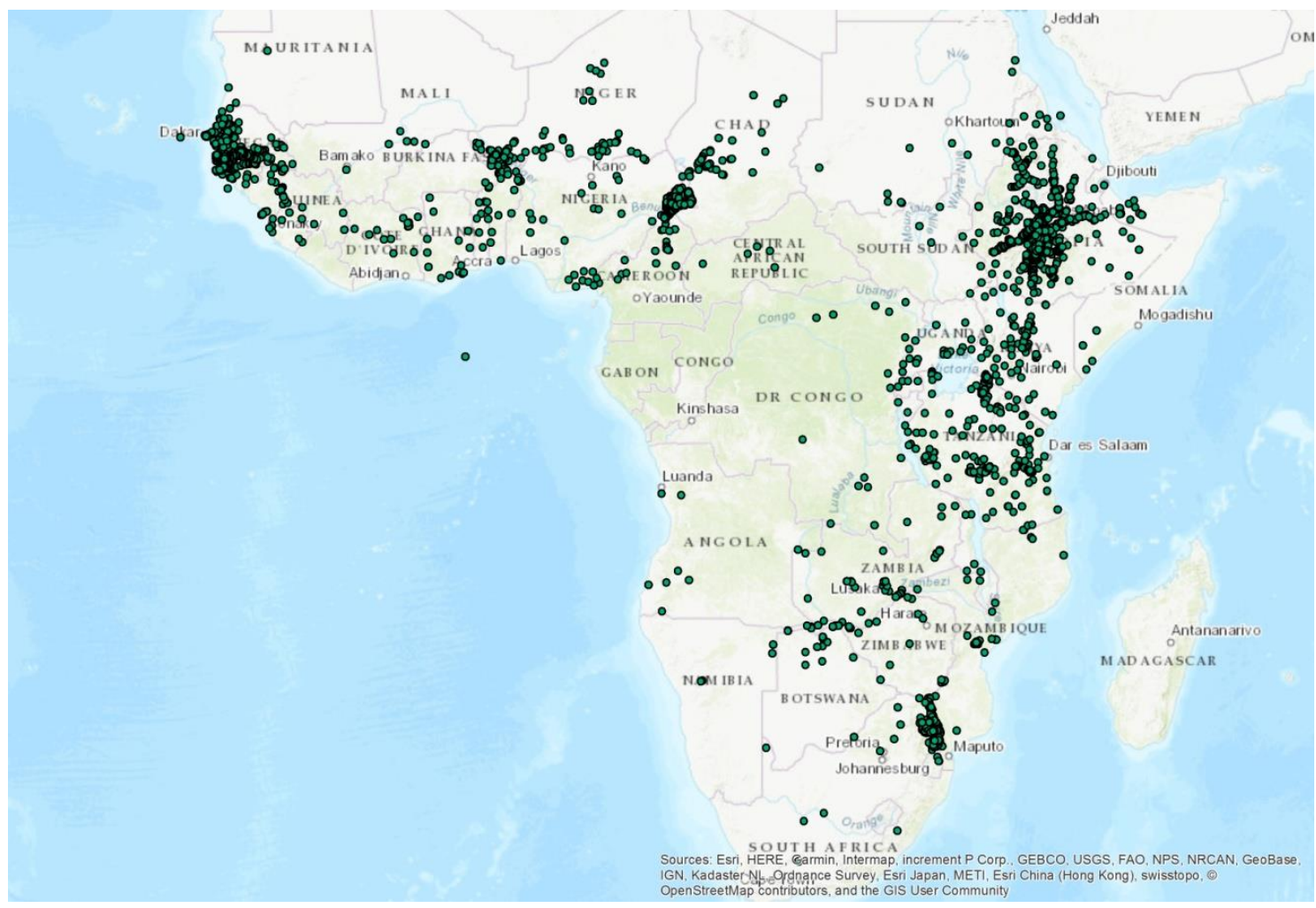

Figure 1: Map of Hooded Vulture Necrosyrtes monachus distribution based on data managed and supplied by African Raptor Data Base (ARDB: June 2019).

\section{Methods}

RPR, GM, and colleagues captured a total of 13 adult Hooded Vultures at two locations in northern Botswana. Three birds in 2014 and one bird in 2015 were trapped in a Wildlife Management Area near Khwai, Botswana $\left(\mathrm{S} 19.53430^{\circ} \mathrm{E} 23.61103^{\circ}\right)$ and nine vultures were trapped in 2017 at the Kazungula, Botswana Crocodile Farm (S17.79511 ${ }^{\circ}$
E25.23125 $)$. We captured birds using bait (either a donkey or goat carcass) and a gas-propelled canon net system. Since we shot baits in the head, we removed the heads to eliminate any lead fragment ingestion (Garbett et al. 2018). On extraction from the net, we put hoods on birds to minimize stress. We collected comprehensive measurements using callipers, a steel rule, a tape measure, and a scale. Biometrics taken included head length, bill length, 
width, and depth, wingspan, wing chord, total body length, girth, tail length, weight, tarsus length, middle toe length, middle talon length, and lengths of primaries 5, 6, and 7. We used the first four measurements in this study. We collected blood and feather samples, and uniquely marked each bird with a leg ring and a wing tag.

SS measured seven heads of the 11 study skin specimens held at the National Museums of Kenya (hereafter NMK) obtained in Kenya, Tanzania and Uganda using a Serving Science calliper. Judith White used the same methods at the Natural History Museum, Tring, UK to measure five feathered heads from five West African countries and three skulls of unknown origins in Africa. CRB and colleagues collected specimens in The Gambia killed by vehicle collisions in coastal Western Region south of the River Gambia. Fatalities are generally found near feeding assemblies of Hooded Vultures scavenging at domestic animal road kill on or at the sides of busy coastal highways. One specimen (HV.02) was found dead of unknown causes in a dry harvested rice paddy with some well-established trees at Kampant (N16.11300 $\mathrm{E} 13.19936^{\circ}$ ) at $\mathrm{c} 130 \mathrm{~km}$ inland and had a gut content of oil palm kernel (Barlow 2004).

Skeletal preparation entailed bringing the corpse home and measuring it. We then loosely wrapped the feathered corpse with the wings, head and neck secured to the body by light cord. It was then placed in a semi-open, punctured container and placed off the ground on bricks open to the elements. Putrefaction of soft parts and cleaning by fly maggot larvae and Dermestidae beetles was rapid during the rains and more protracted in the dry season. After the specimen was de-fleshed and semi-dry, we manually separated remaining attached feathers and skin from the skeletal remains. Sometimes soaking in warm water aided the process. If required, we further cleaned the bones by hand, using a small brush and mild detergents and diluted household bleach. All large bones were then sun dried on a towel and smaller ones on absorbent kitchen paper. We put the bones in sealable plastic storage freezer bags and labelled them. We made skull measurements using a Clarke calliper. The bill rhamphothecae on both the lower and upper mandibles was attached on all the Gambian specimens excepting Gam.HV02. Sex was unknown for any of the birds in The Gambia or Botswana sample. Age class from all birds from the museum specimen is indicated when known.

We conducted all analyses in the statistical program JMP 15.0. We ran a nominal logistic model with the putative subspecies as the dependent variable and head length, bill length, bill width, and bill depth as the independent variables. We also conducted a hierarchical clustering using the Ward method to examine how specimens grouped using the same independent variables and then using bill width only.

\section{Results}

We gathered data on 13 Hooded Vultures from Botswana in southern Africa, seven birds from East Africa, 14 individuals from West Africa, and 3 birds of unknown origin (Table 2). We found little morphological evidence for maintaining the two putative subspecies of Hooded Vultures based on the morphometrics of the head and skull using the variables of head length, bill length, bill depth, and bill width. Three of these do not differ significantly between birds from West Africa and those from East and southern Africa (Table 3, Figure 2). Bill width differed significantly between the two putative subspecies (Table 3, Figure 2), but we found substantial overlap in those measurements. Hierarchical analyses using all of the variables we measured and using only bill width (the only significant variable) found no clear delineation between the putative subspecies (Figure 3). 
Table 2. Hooded Vulture (Necrosyrtes monachus) head and bill measurements (in mm).

\begin{tabular}{|c|c|c|c|c|c|c|c|c|}
\hline Country & Subspecies & ID & $\begin{array}{l}\text { Collection } \\
\text { date }\end{array}$ & Age & $\begin{array}{l}\text { Head } \\
\text { length }\end{array}$ & $\begin{array}{l}\text { Bill } \\
\text { length }\end{array}$ & $\begin{array}{l}\text { Bill } \\
\text { width }\end{array}$ & $\begin{array}{l}\text { Bill } \\
\text { depth }\end{array}$ \\
\hline Botswana & pileatus & 183 & $15 / 03 / 2014$ & Juvenile & 111.0 & 57.5 & 19.0 & 17.0 \\
\hline Botswana & pileatus & 185 & $15 / 03 / 2014$ & Adult & 120.0 & 65.5 & 21.0 & 17.0 \\
\hline Botswana & pileatus & 186 & $15 / 03 / 2014$ & $\mathrm{Ad}$ & 102.5 & 55.1 & 18.0 & 13.5 \\
\hline Botswana & pileatus & CNV1 & $22 / 03 / 2017$ & Adult & 111.0 & 62.0 & 22.0 & 23.0 \\
\hline Botswana & pileatus & CHV2 & $22 / 03 / 2017$ & Adult & 111.5 & 58.0 & 24.0 & 22.0 \\
\hline Botswana & pileatus & CHV3 & $22 / 03 / 2017$ & Adult & 110.0 & 59.5 & 24.5 & 19.5 \\
\hline Botswana & pileatus & CHV4 & $22 / 03 / 2017$ & Adult & 110.0 & 60.0 & 22.0 & 19.0 \\
\hline Botswana & pileatus & CHV5 & $22 / 03 / 2017$ & Juvenile & 118.5 & 63.5 & 24.0 & 20.5 \\
\hline Botswana & pileatus & CHV6 & $22 / 03 / 2017$ & Adult & 113.5 & 62.0 & 25.0 & 23.0 \\
\hline Botswana & pileatus & CHV7 & $22 / 03 / 2017$ & Adult & 113.0 & 61.0 & 23.5 & 23.0 \\
\hline Botswana & pileatus & 731 & $22 / 03 / 2017$ & Juvenile & 102.5 & 67.0 & 20.0 & 17.5 \\
\hline Botswana & pileatus & None & $22 / 03 / 2017$ & Adult & 112.0 & 61.5 & 25.0 & 18.5 \\
\hline Botswana & pileatus & 702 & $25 / 07 / 2015$ & Juvenile & 111.7 & 55.1 & 26.1 & 22.3 \\
\hline Kenya & pileatus & 25366 & $29 / 09 / 1943$ & Unknown & 117.8 & 61.2 & 21.5 & 22.5 \\
\hline Tanzania & pileatus & 25364 & $3 / 6 / 1917$ & Unknown & 113.3 & 52.8 & 24.5 & 22.3 \\
\hline Kenya & pileatus & 25362 & $27 / 12 / 1950$ & Unknown & 118.7 & 61.0 & 19.2 & 21.1 \\
\hline Tanzania & pileatus & 25367 & $6 / 8 / 1917$ & Unknown & 115.1 & 59.5 & 20.7 & 20.3 \\
\hline Uganda & pileatus & 25361 & $13 / 06 / 1923$ & Unknown & 112.8 & 60.5 & 19.3 & 24.7 \\
\hline Kenya & pileatus & 25360 & $29 / 09 / 1943$ & Unknown & 111.4 & 63.5 & 18.4 & 23.7 \\
\hline Kenya & pileatus & None & $9 / 2 / 1930$ & Unknown & 118.0 & 62.3 & 19.5 & 17.8 \\
\hline The Gambia & monachus & Gam.HV01 & $15 / 01 / 2002$ & Adult & 116.6 & 64.9 & 22.0 & 21.8 \\
\hline The Gambia & monachus & Gam.HV02 & $9 / 2 / 2002$ & Unknown & 103.0 & 57.0 & 17.5 & 19.6 \\
\hline The Gambia & monachus & Gam.HV03 & $10 / 3 / 2005$ & Juvenile & 113.2 & 65.0 & 19.7 & 19.4 \\
\hline The Gambia & monachus & Gam.HV04 & $3 / 4 / 2006$ & Adult & 114.0 & 61.5 & 17.5 & 23.4 \\
\hline The Gambia & monachus & GamHV.05 & $29 / 01 / 2018$ & Unknown & 111.3 & 64.0 & 17.2 & 24.0 \\
\hline The Gambia & monachus & Gam.HV06 & $14 / 10 / 2019$ & Unknown & 111.0 & 61.0 & 18.0 & 22.0 \\
\hline The Gambia & monachus & Gam.HV07 & $7 / 7 / 2019$ & Unknown & 114.5 & 64.3 & 20.0 & 21.7 \\
\hline The Gambia & monachus & Gam HV08 & $5 / 6 / 2019$ & Juvenile & 117.8 & 60.0 & 19.3 & 20.0 \\
\hline N. Cameroon & monachus & NHMUK 1923.10.26.62 & $28 / 10 / 1922$ & Unknown & & 59.2 & & \\
\hline Sierra Leone & monachus & NHMUK 1920.6.15.1 & $9 / 3 / 1920$ & Unknown & & 65.9 & 15.1 & \\
\hline $\begin{array}{l}\text { Portuguese } \\
\text { Guinea }\end{array}$ & monachus & NHMUK 1910.5.6.103 & $13 / 6 / 1909$ & Unknown & 106.5 & 61.7 & 16.1 & \\
\hline The Gambia & monachus & NHMUK 1929.2.18.1 & $6 / 1 / 1929$ & Unknown & 100.0 & 59.0 & 15.8 & \\
\hline $\begin{array}{l}\text { Cape Coast } \\
\text { Castle }\end{array}$ & monachus & NHMUK 1895.5.1.13 & $7 / 3 / 1832$ & Unknown & 109.4 & 62.8 & 17.0 & \\
\hline Gold Coast & monachus & NHMUK 1911.12.18.136 & $22 / 12 / 1910$ & Unknown & & 57.4 & 15.0 & \\
\hline Unknown & unk & NHMUK S/1954.30.117 & Unknown & Unknown & 108.0 & 58.0 & 18.1 & \\
\hline Unknown & pileatus & NHMUK S/1952.3.209 & Unknown & Unknown & 111.0 & 61.0 & 17.1 & \\
\hline Unknown & pileatus & NHMUK S/1952.3.206 & Unknown & Unknown & 102.2 & 54.4 & 17.5 & \\
\hline
\end{tabular}

Table 3. Nominal logistic model results comparing bill measurements and head lengths of putative Hooded Vulture Necrosyrtes monachus subspecies, N. m. monachus and N. m. pileatus from throughout Africa.

\begin{tabular}{|l|c|c|c|c|c|}
\hline Variable & Estimate & \multicolumn{1}{l|}{ SE } & \multicolumn{1}{l|}{ df } & Likelihood ratio $\boldsymbol{X}^{\mathbf{2}}$ & $\boldsymbol{P}$ \\
\hline Head length & 0.041 & 0.113 & 1 & 0.129 & 0.72 \\
\hline Bill length & 0.231 & 0.201 & 1 & 1.370 & 0.24 \\
\hline Bill width & -0.879 & 0.445 & 1 & 9.084 & $<.01$ \\
\hline Bill depth & 0.159 & 0.215 & 1 & 0.578 & 0.44 \\
\hline
\end{tabular}



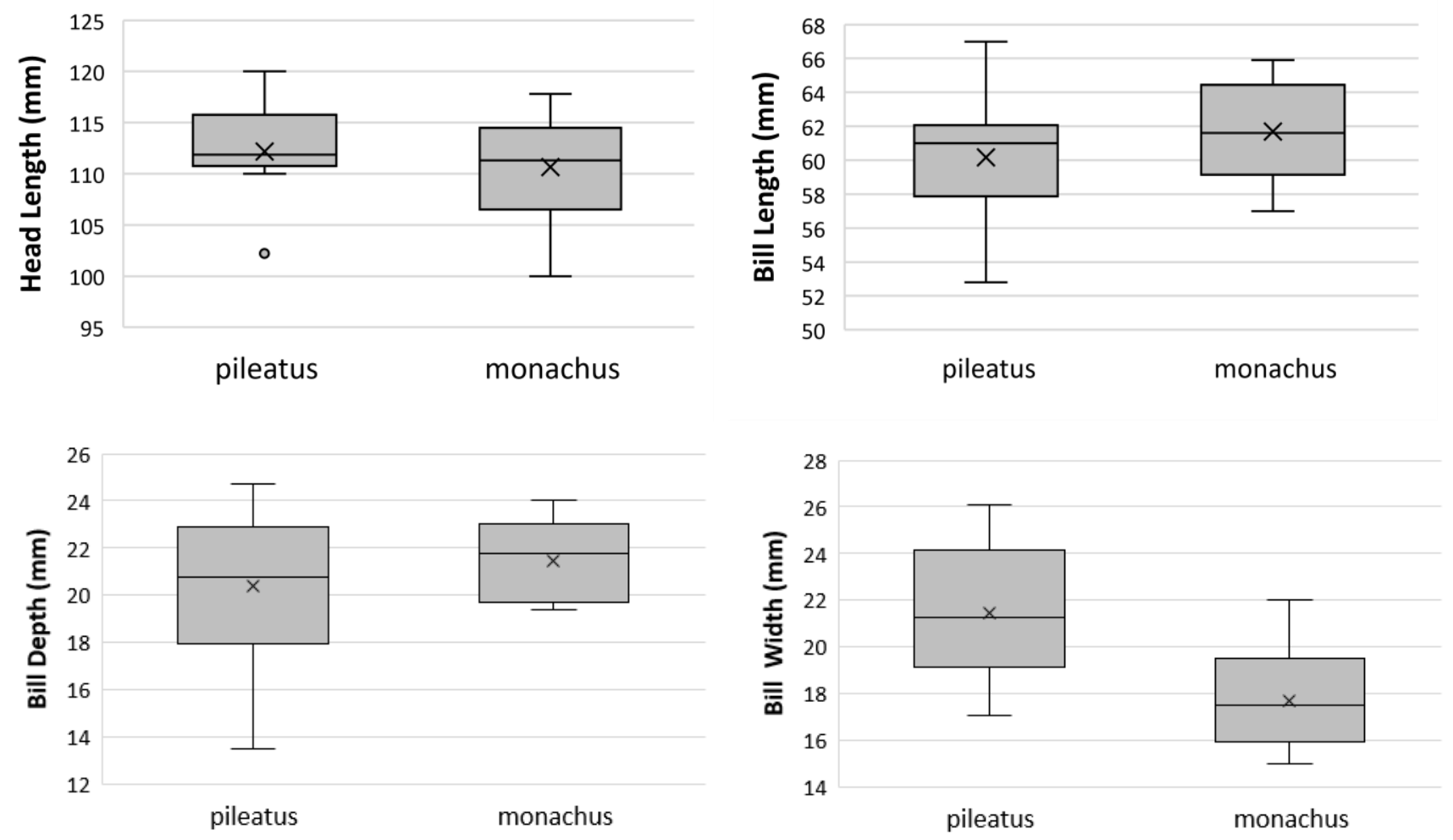

Figure 2: Comparison of head length and bill length, depth and width measurement for two putative Hooded Vulture (Necrosyrtes monachus) subspecies, N. m. monachus and N. m. pileatus.

\section{Discussion}

Debate has continued for decades on the validity of the putative subspecies designations for Hooded Vultures (see Table 1). Our analysis involving 37 individuals suggests that the species does not vary significantly in several skull measurements across it range. Indeed, we found substantial overlap in all the measurements we assessed. These results corroborate the opinion of Mundy et al. (1992) that the species, while exhibiting a size gradient from West Africa through East Africa to southern Africa, does not merit subspecific designations. Clark \& Davies (2018) also argue that the species is monotypic. A clinal size difference may occur with smaller birds in West Africa, followed by slightly larger birds in East Africa and the largest birds in southern Africa (Mundy et al. 1992, Del Hoyo et al. 1994), but we did not find evidence for such a cline in the measurements we gathered. The authors, along with a network of collaborators, will continue with fieldwork dealing with an assortment of foraging, ecological, and reproductive studies, as well as continued monitoring of population trends. The studies will include where there are current strongholds (e.g., The Gambia: Jallow et al. 2016, Barlow \& Fulford 2013); and Guinea-Bissau: (Henriques et al. 2017, 2018) and where declines are occurring e.g. Dakar, Senegal: Mullié et al. 2017; Nigeria: Nosazeogie et al. 2018; and Botswana: Reading et al. 2019) and throughout their range (Pomeroy et al 2015, Thompson et al. 2020). 

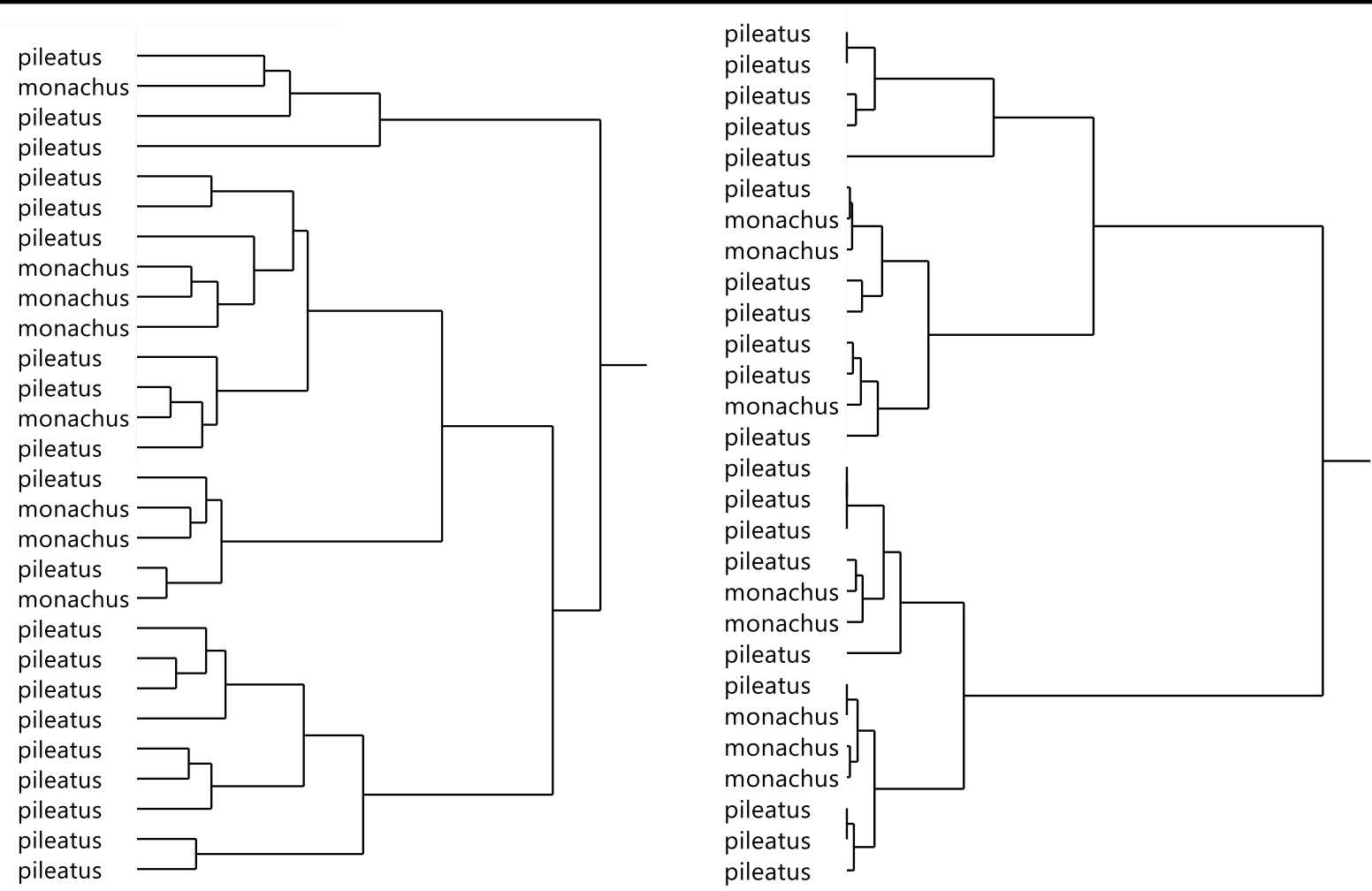

Figure 3: Hierarchical distribution of putative Hooded Vulture Necrosyrtes monachus subspecies, N. $m$. monachus $(\mathrm{n}=20)$ and $N$. m. pileatus $(\mathrm{n}=8)$. Analyses conducting using head length and bill length, depth and width (left) and only bill width (right). Note the lack of a clear distinction between the putative subspecies.

\section{Conclusion}

Based on our results raised from a set of cranial biometrics assembled from three areas across the range of the Hooded Vulture we find little or no new morphological evidence to support the status of two subspecies. Our findings concur with the deductions of other authors past and present that the Hooded Vulture is monotypic. A road-killed Hooded Vulture specimen from The Gambia (GamHV.04) is genetically sequenced from a tissue sample and the results are accessible at GenBank (https://www.ncbi.nim.gov/genbank Lerner \& Mindell 2005). It remains the task of geneticists to investigate further regional populations and bring closure to this enduring taxonomic question noting that morphology may not automatically reflect molecular phylogeny, as proven by Collinson et al. (2017).

\section{Acknowledgments}

Judith White helpful at all times kindly provided the measurements made at the collection at the Natural History Museum, Tring, U.K and supplied other important information for this enquiry. In The Gambia CRB thanks R. Cryer, F. Mendy, G. Dobbs and the Department of Parks and Wildlife Management and West African Bird Study Association for assistance with this vulture work. Washington Waschira kindly assisted us with personal introductions in Kenya. SS thanks the Ornithology Section of the National Museums of Kenya, for granting permission to use their specimens for the study. RPR and GM thank D. Kenny, J. Bradley, T. David, R. Garbett, P. Hancock, M. Keiteretse, and M. Selebatso, B. Funding provided by Denver Zoo, Raptors Botswana, The Rufford Foundation, a Fulbright 
Fellowship, and the Wilderness Wildlife Trust. We thank Peter Mundy for sharing knowledge and contributing helpful correspondence. Rob Davies and Simon Trice at the African Raptor Data Base kindly supplied the up to date distribution map. Esther Nosazeogie AP Leventis Ornithological Research Institute, Jos discussed collaborative field work in Nigeria. Jason Waine supplied the data for
Gam.HV01 and made comments on an earlier draft. Dave Montrieul supplied the Gambian preening picture. Neil Baker, Darcy Ogada and Frank Gill kindly assisted with references. Derek Pomeroy and Micheal Kibule discussed Hooded Vultures in Kampala and from where Betty Lutaaya helped expediently with publications.

\section{References}

Bannerman, D.A. 1930. The Birds of Tropical West Africa, Vol. 1. Crown Agents. London.

Barlow, C.R. 2004. The utilization of oil-palm kernel by Necrosyrtes monachus in The Gambia. Vulture News 51: 60-62.

Barlow, C.R. \& Fulford, T. 2013. Road counts of Hooded Vultures Necrosyrtes monachus over seven months in and around Banjul, coastal Gambia, in 2005.Malimbus 35: 50-56.

Benson, C.W., Brooke,. R.K., Dowsett, R.J. \& Irwin, M.P.S. 1971. The Birds of Zambia. Collins. London.

Borrow, N. \& Demey, R. 2001. Birds of Western Africa. Christopher Helm. London

Brown, L.H., Urban, E.K \& Newman, K. (eds). 1982. The Birds of Africa, Vol 1. Academic Press, London.

Clark, W.S. \& Davies R. 2018. African Raptors. Bloomsbury Helm. London.

Collinson, J.M., Dufour,P., Hamza, A., Lawrie, Y., Elliot, M., Barlow, C.R., \& Crochet, P-A. 2017. When morphology is not reflected by molecular phylogeny: the case of three 'orange-billed terns' Thalasseus maximus, Thalasseus bergii and Thalasseus bengalensis (Charadriiformes: Laridae) Biological Journal of the Linnean Society 121: 439-445.

Del Hoyo, J., Elliott, A. \& Sargatal, J. (eds). 1994. Handbook of the Birds of the World. Vol 2. Lynx Edicions, Barcelona.

Dowsett, R.J., Aspinwall, D.R. \& Dowsett-Lemaire, F. 2008. The Birds of Zambia. Tauraco Press and Aves a.s.b.1. Liège. Belgium.

Garbett, R., Maude, G., Hancock, P., Kenny, D., Reading, R., \& Amar, A. 2018. Association between hunting and elevated blood lead levels in the critically endangered African White-backed Vulture Gyps africanus. Science of the Total Environment 630: 1654-1665.

Gibbon, G. 2018. Roberts VII Multimedia Birds of Southern Africa, Android Edition, version 3.14. South African Birding CC, Westville, South Africa.

Gill F., Donsker, D. \& Rasmussen, P. (Eds). 2020. IOC World Bird List (v10.1). doi : 10.14344/IOC.ML.10.1.

Henriques, M., Granadeiro, J. P., Monteiro, H., Nuno, A., Lecoq, M., Cardoso, P., Regalla, A., \& Catry, P. 2018. Not in wilderness: African vulture strongholds remain in areas with high human density. PLoS ONE 13: e0190594.

Henriques, M., Lecoq, M., Monteiro, H., Regalla, A., Granadeiro, J. P., and Catry, P. 2017. Status of birds of prey in Guinea-Bissau: First assessment based on road surveys. Ostrich 88: 101-111. 
Jallow, M., Barlow, C. R., Sanyang, L., Dibba, L., Kendall, C., Bechard, M., \& Bildstein, K. L. 2016. High population density of the critically endangered Hooded Vulture Necrosyrtes monachus in Western Region, The Gambia, confirmed by road surveys in 2013 and 2015. Malimbus 38: 23-28

Lerner, H.R.L. \& Mindell, D.P. 2005. Phylogeny of eagles, Old World vultures and other Accipitridae based on nuclear and mitochondrial DNA. Molecular Phylogenetics and. Evovultion 37: 327-346.

Mackworth-Praed, C.W.\& Grant C.H.B. 1970. Birds of West Central and Western Africa, African Handbook of Birds. Ser. 3. Vol 1. Longman.. London.

Mackworth-Praed, C.W.\& Grant C.H.B. 1981. Birds of The Southern Third of Africa. African Handbook of Birds. Ser. 2. Vol 1. Longman. London

Mullié W.C., Couzi F., Diop M.S., Piot B., Peters T., Reynaud P.A., \& Thiollay J. 2017. The decline of an urban Hooded Vulture Necrosyrtes monachus population in Dakar, Senegal, over 50 years. Ostrich 88: $131-138$.

Mundy, P., Butchart, D., Ledger, J. \& Piper, S. 1992. The Vultures of Africa. Academic Press, London.

Nosazeogie, E. \& Tende, T. \& Monadjem, A. 2018. Hooded Vultures Necrosyrtes monachus nearly extirpated from Edo State, Nigeria: a report on the avian scavenger community. Ostrich 89: 265-273.

Ogada, D.L. \& Buij, R. 2011. Large declines of the Hooded Vulture Necrosyrtes monachus across its African range. Ostrich 82: 101-113.

Pomeroy, D., Shaw, P., Opige, M., Kaphu., G., Ogada., \& Virani, M. Z. 2015.. Vulture populations in Uganda: using road survey data to measure both densities and encounter rates within protected and unprotected areas. Bird Conservation International 25: 399-414.

Reading, R. P., Bradley, J., Hancock, P., Garbett, R., Selebatso, M., \& Maude, G. 2019. Home range size and movement patterns of hooded vultures Necrosyrtes monachus in southern Africa. Ostrich 90: 7377.7

Redman, N., Stevenson, T. \& Fanshawe, J. 2009. Birds of the Horn of Africa. Christopher Helm. London.

Thompson, L. J., Barber, D., Bechard, M., Botha, A. J., Wolter, K., Neser, W., Buechley, E. R., Reading, R., Garbett, R., Hancock, P., Maude, G., Virani, M. Z., Thomsett, S., Lee, H., Ogada, D., Barlow, C. R. \& Bildstein, K. L. 2020. Variation in monthly sizes of home-ranges of Hooded Vultures Necrosyrtes monachus in western, eastern, and southern Africa. Ibis. doi: 10.1111/ibi.12836

Zimmerman, D.A., Turner, D.A \& Pearson, D.J. 1996. Birds of Kenya and Northern Tanzania. Christopher Helm. London. 